\title{
Hydrogen Peroxide Is Crucial for NLRP3 Inflammasome-Mediated IL-1 $\beta$ Production and Cell Death in Pneumococcal Infections of Bronchial Epithelial Cells
}

\author{
Surabhi Surabhi Lana H. Jachmann Patience Shumba Gerhard Burchhardt \\ Sven Hammerschmidt Nikolai Siemens \\ Department of Molecular Genetics and Infection Biology, Interfaculty Institute for Genetics and Functional \\ Genomics, Center for Functional Genomics of Microbes, University of Greifswald, Greifswald, Germany
}

\author{
Keywords \\ Streptococcus pneumoniae - NLRP3 inflammasome · \\ Cell death · Caspase- 1 - Caspase-3/7 · IL-1 $\beta$ Pyroptosis · \\ Apoptosis
}

\begin{abstract}
Epithelial cells play a crucial role in detection of the pathogens as well as in initiation of the host immune response. Streptococcus pneumoniae (pneumococcus) is a typical colonizer of the human nasopharynx, which can disseminate to the lower respiratory tract and subsequently cause severe invasive diseases such as pneumonia, sepsis, and meningitis. Hydrogen peroxide $\left(\mathrm{H}_{2} \mathrm{O}_{2}\right)$ is produced by pneumococci as a product of the pyruvate oxidase SpxB. However, its role as a virulence determinant in pneumococcal infections of the lower respiratory tract is not well understood. In this study, we investigated the role of pneumococcal-derived $\mathrm{H}_{2} \mathrm{O}_{2}$ in initiating epithelial cell death by analyzing the interplay between 2 key cell death pathways, namely, apoptosis and pyroptosis. We demonstrate that $\mathrm{H}_{2} \mathrm{O}_{2}$ primes as well as activates the NLRP3 inflammasome and thereby mediates IL-1 $\beta$ production and release. Furthermore, we show that pneumococcal $\mathrm{H}_{2} \mathrm{O}_{2}$ causes cell death via the activation of both
\end{abstract} www.karger.com/jin

Karger!"

BOPEN ACCESS karger@karger.com
(C) 2021 The Author(s)

Published by S. Karger AG, Basel

This is an Open Access article licensed under the Creative Commons Attribution-NonCommercial-4.0 International License (CC BY-NC) (http://www.karger.com/Services/OpenAccessLicense), applicable to the online version of the article only. Usage and distribution for commercial purposes requires written permission. apoptotic as well as pyroptotic pathways which are mediated by the activation of caspase- $3 / 7$ and caspase- 1 , respectively. However, $\mathrm{H}_{2} \mathrm{O}_{2}$-mediated IL-1 $\beta$ release itself occurs mainly via apoptosis.

(c) 2021 The Author(s)

Published by S. Karger AG, Basel

\section{Introduction}

Streptococcus pneumoniae (pneumococcus), a Grampositive bacterium and a typical asymptomatic colonizer of the human upper respiratory tract, remains the most commonly identified cause of community-acquired pneumonia [1]. Pneumococci are equipped with a variety of virulence factors allowing them to circumvent the host immune response. In many cases, initial mild manifestations may result in severe invasive diseases such as pneumonia, meningitis, and sepsis [2,3]. One of the most important and well-studied secreted virulence factors of pneumococci is the pore-forming cytolysin pneumolysin (Ply) [4]. Moreover, pneumococci secrete high amounts of hydrogen peroxide $\left(\mathrm{H}_{2} \mathrm{O}_{2}\right)$ as a product of the pneumococcal carbohydrate-metabolizing enzyme pyruvate oxidase $\mathrm{SpxB}$ [5]. It is believed that secreted $\mathrm{H}_{2} \mathrm{O}_{2}$ dif-

Correspondence to:

Nikolai Siemens, nikolai.siemens@ uni-greifswald.de 
fuses through the host cell membrane and causes oxidative damage [6]. Consequently, Spellerberg and colleagues have shown that $S$. pneumoniae mutants deficient in $\mathrm{H}_{2} \mathrm{O}_{2}$ production are characterized by a reduced virulence in vivo [5]. Furthermore, it was demonstrated that pneumococci-derived $\mathrm{H}_{2} \mathrm{O}_{2}$ is a major vasodilator and contributes to the cerebral hyperemia during early stages of meningitis and therapies with antioxidants attenuate the pathophysiological responses $[7,8]$. In vitro studies with cells of the respiratory tract showed that both $\mathrm{H}_{2} \mathrm{O}_{2}$ and Ply attenuate ciliary function by (i) slowing down the ciliary beat frequency and (ii) impairing the structural integrity of human ciliated epithelium $[9,10]$. Furthermore, studies on rat alveolar epithelial cells have demonstrated that cell injury induced by $S$. pneumoniae mutants that lacked Ply activity was comparable to that of the parental strain. $\mathrm{H}_{2} \mathrm{O}_{2}$ was identified as a major factor responsible for the cell cytotoxicity [11].

Epithelial cells span the entire length of the respiratory tract and were initially presumed to solely serve as a physical barrier for inhaled particles or microorganisms [12]. However, many studies have shown their significance as important immune sentinels $[13,14]$. They possess a diverse repertoire of pattern-recognition receptors that assist in detection of various pathogen and danger-associated molecular patterns [15]. Once the healthy host cells encounter a death-inducing stimulus, they can initiate a variety of molecular cell death pathways. Apoptosis is a controlled form of cell death, which features the activation of initiator caspases like caspases-2, 8, 9, and 10. Subsequently, these caspases activate effector caspases such as caspases-3, 6, and 7 [16]. Once activated, the effector caspases cleave various intracellular substrates, including a-fodrin, gelsolin, $\mathrm{p} 21$-activated kinase 2 , and inhibitor of caspase-activated DNase/DNA fragmentation factor-45 [17]. The final stage of apoptotic cell death includes the formation of apoptotic bodies which expose surface molecules. Professional phagocytes including macrophages recognize the apoptotic bodies and ingest them, making this form of cell death less inflammatory in nature [16].

Pyroptosis is another form of programmed cell death, and in contrast to apoptosis, it is more of a pro-inflammatory nature. Pyroptosis is driven by the activation of a diverse range of inflammasomes. Inflammasomes are multiprotein complexes that assemble based on the detection of danger signals [18]. Of the various inflammasomes, NLRP3 inflammasome is the most unique as it is activated by a wide range of stimuli, such as whole pathogens [19], extracellular ATP [20], and pathogen-associated RNA and toxins $[21,22]$. The NLRP3 inflammasome is activated in a two-step process, namely priming and activation $[23,24]$. The priming step is essential to increase the intracellular concentrations of NLRP3 and pro-interleukin (IL)-1 $\beta$. The transcription factor NF- $\mathrm{kB}$ is activated upon detection of a priming signal via toll-like receptors, tumor necrosis factor receptors, or interleukin-1 receptors. NF- $\mathrm{kB}$ further upregulates the gene expression of NLRP 3 and pro-IL- $1 \beta$. However, the priming step itself does not result in IL- $1 \beta$ secretion. Next, the exposure to an activating signal leads to the assembly and activation of the NLRP3 inflammasome [18]. Active NLRP3 inflammasome converts recruited procaspase-1 to bioactive caspase- 1 , which further cleaves inactive proIL- $1 \beta$ and pro-IL- 18 into mature IL- $1 \beta$ and IL- 18 , respectively. Furthermore, caspase- 1 cleaves $50-\mathrm{kDa}$ gasdermin-D (GSDMD) into an active 30-kDa GSDMD-N (Nterminal domain of GSDMD) fragment. GSDMD-N integrates into the cell membrane and forms pores through which IL- $1 \beta$ and IL-18 are secreted into the extracellular space. This form of controlled cell lysis is termed pyroptotic cell death [25-27].

It must be noted that although previous studies indicate the importance of pneumococcal $\mathrm{H}_{2} \mathrm{O}_{2}$ in causing cell damage, not much is known about its impact on the activation of cell death pathways. A study by Erttmann and Gekara [28] suggested that $\mathrm{H}_{2} \mathrm{O}_{2}$ blocks ATP-mediated NLRP3 inflammasome activation in mouse macrophages. However, this study analyzed exclusively very early events (30 $\mathrm{min}$ ) of pneumococcal infections and was limited to inflammasome activation and not cell death. In contrast, studies on human macrophages suggest that NLRP3 is activated in reactive oxygen species-sensitive manner including $\mathrm{H}_{2} \mathrm{O}_{2}[29,30]$. Furthermore, it was shown that the addition of $\mathrm{H}_{2} \mathrm{O}_{2}$ alone to human THP-1 macrophages is sufficient to trigger NLRP3-caspase 1 -mediated IL- $1 \beta$ release [30].

Here, we aimed to analyze the impact of pneumococciderived $\mathrm{H}_{2} \mathrm{O}_{2}$ on cell death pathways. We show that $\mathrm{H}_{2} \mathrm{O}_{2}$ damages bronchial epithelial cells and induces caspase-1 activation, resulting in IL- $1 \beta$ release. However, GSDMD$\mathrm{N}$, a cleavage product of caspase- 1 , was not detected and therefore, IL-1 $\beta$ is mainly released through the apoptotic pathway.

\section{Materials and Methods}

Bacterial Strains

Encapsulated S. pneumoniae wild-type strains TIGR4, 19F, and D39 and nonencapsulated $S$. pneumoniae D39 $\Delta c p s$ and its isogenic mutants $\Delta c p s \Delta p l y, \Delta c p s \Delta s p x B$, and $\Delta c p s \Delta p l y \Delta s p x B$ were cul- 
tured on Columbia blood agar plates (Oxoid) and in Todd-Hewitt broth supplemented with $0.5 \%$ (w/v) yeast extract (THY; Roth). Streptococcus pyogenes strain 5448 was cultured overnight in THY [31]. Staphylococcus aureus strain LUG2012 (USA300 lineage) was cultured overnight at $37^{\circ} \mathrm{C}$ in casein hydrolysate and yeast extract medium with agitation [32]. All static bacterial cultures were maintained at $37^{\circ} \mathrm{C}$ and $5 \% \mathrm{CO}_{2}$. For growth analysis, pneumococcal strains were cultured in THY, and the growth behavior was monitored by measuring the optical density $\left(\mathrm{OD}_{600 \mathrm{~nm}}\right)$.

\section{S. pneumoniae Mutant Generation}

Genomic DNA of the D39 $\Delta c p s$ strain served as a template for the knock-out of the ply gene (SPD1726). Briefly, SPD1725 was amplified using the following primers: $5^{\prime}$-CGGGATCCGCAAATAAAGCAGTAAATGAC- ${ }^{\prime}$ and $5^{\prime}$-GACTCTAGAGGATCCCCGGGTCAACAGACACTCATCCACATTC-3'. The resulting PCR product was digested with SacII, ligated into the pGEM-T Easy vector, and transformed into E. coli DH5a. To delete the ply gene, the recombinant plasmid was used as a template for an inverse PCR with the following primers: $5^{\prime}$-CTATTTGGGGATCGATTCTCTATCCTCAGG- $3^{\prime}$ and $5^{\prime}$-CCGGAAGCTTAACAGCGTCTACGCTGACTGTATA-3'. The chloramphenicol $(\mathrm{Cm})$ resistance gene cassette was amplified using the following primers: 5'-CGCGAAGCTTCGAAAATTTGTTTGATTTTTAATGG- $3^{\prime}$ and $5^{\prime}$-GATAATCGATCGGGTTCCGAGGCTCAACGTCAA- $3^{\prime}$. Both PCR products were digested with ClaI and HindIII, ligated, and transformed into E. coli DH5a. The resulting recombinant plasmid pGEM-T $\Delta p l y:: C m$ was transformed into S. pneumoniae D39 $\Delta$ cps as described previously $[33,34]$. Recombinant $S$. pneumoniae clones were selected on blood agar containing chloramphenicol $(5 \mu \mathrm{g} / \mathrm{mL})$. Replacement of the ply gene was analyzed via PCR using the following primers: $5^{\prime}$-CGGGATCCGCAAATAAAGCAGTAAATGAC- $3^{\prime}$ and $5^{\prime}$-GCGGTACCCTAGTCATTTTCTACCTGAG-3'.

Genomic DNA of the D39 $\Delta s p x B$ mutant, which was kindly provided by K. Mühlemann (University of Bern, Bern, Switzerland) [35], served as a template for $s p x B$ gene knock-out. Briefly, the mutated $s p x B$ gene region containing the erythromycin (ermB) resistance gene cassette was amplified using the following primers: $5^{\prime}$-GGAGAACGTTTCCAATTCTATG- ${ }^{\prime}$ ' and $5^{\prime}$-GACCGGATTGCTCCGATCTT-3'. The resulting 3.1-kb fragment was digested with $X c m I$, ligated into the pGXT plasmid (Promega), and transformed into E. coli DH5a. The purified pGXT-spxB:erm plasmid was used for transformation of D39 $\Delta c p s$ and $\Delta c p s \Delta p l y$ as described previously $[33,34]$. Bacteria were grown for $2 \mathrm{~h}$ at $37^{\circ} \mathrm{C}$ and plated on blood agar plates containing $5 \mu \mathrm{g} / \mathrm{mL}$ erythromycin. The resulting $S$. pneumoniae D39 spxB-deficient mutants were screened by colony PCR using the following primers: 5 '-GCGCGCTAGCACTCAAGGGAAAATTACTGC- $3^{\prime}$ and $5^{\prime}$-GCGCGAGCTCTTATTTAATTGCGCGTGATTG-3'. Gene organization in D39 $\Delta c p s$ and respective mutant strains are depicted in online suppl. Figure 1; see www.karger.com/doi/10.1159/000517855 for all online suppl. material.

In addition, the lack of SpxB and Ply was confirmed via Western blot analyses. Briefly, D39 $\Delta c p s$ mutants were cultivated in THY medium until the late exponential growth phase was reached, bacteria were lysed, and protein extracts were separated via SDSPAGE and transferred onto a nitrocellulose membrane. For detection of SpxB and Ply [36], mouse polyclonal antibodies (in-house production by the laboratory of S.H.) were used.
Measurement of $\mathrm{H}_{2} \mathrm{O}_{2}$ Production by Pneumococci

$S$. pneumoniae strains were cultured in a chemically defined medium (RPMI1640 containing $2 \mathrm{mM} \mathrm{L-glutamine} \mathrm{medium} \mathrm{[Hy-}$ Clone] supplemented with $30.5 \mathrm{~mm}$ glucose, $0.65 \mathrm{~mm}$ uracil, 0.27 $\mathrm{mM}$ adenine, $1.1 \mathrm{mM}$ glycine, $0.24 \mathrm{mM}$ choline chloride, $1.7 \mathrm{mM}$ $\mathrm{NaH}_{2} \mathrm{PO}_{4} \cdot \mathrm{H}_{2} \mathrm{O}, 3.8 \mathrm{mM} \mathrm{Na}_{2} \mathrm{HPO}_{4} \cdot 2 \mathrm{H}_{2} \mathrm{O}$, and $27 \mathrm{~mm} \mathrm{NaHCO}$ ) at $37^{\circ} \mathrm{C}$ and $5 \% \mathrm{CO}_{2}$ without agitation $\left(\mathrm{OD}_{600 \mathrm{~nm}}\right.$ of $\left.0.80-1.0\right)$ [37]. Bacteria were pelleted at $10,000 \times g$ for $2 \mathrm{~min}$ and the culture supernatants were collected. Five hundred microliters of the culture supernatant was mixed with $500 \mu \mathrm{L}$ Titanium-(IV)-oxide-sulfatesulfuric acid solution (Sigma-Aldrich). The samples were incubated at room temperature in the dark for $5 \mathrm{~min}$ and the OD of the resulting solution was determined at $407 \mathrm{~nm}$. A standard curve containing defined concentrations of $\mathrm{H}_{2} \mathrm{O}_{2}$ was used to determine $\mathrm{H}_{2} \mathrm{O}_{2}$ concentrations in bacterial culture supernatants.

\section{Infections, Stimulations, and Cell Culture Conditions}

Bronchial epithelial 16HBE14o-cells (16HBE) were used in all infection and stimulation experiments. Cells were cultured in a minimum essential medium (Gibco) supplemented with $10 \%$ (v/v) fetal bovine serum (Life Technologies), 2 mM L-glutamine (Invitrogen), $10 \mathrm{mM}$ HEPES, and $1 \%(\mathrm{v} / \mathrm{v})$ minimal essential amino acids (both GE Healthcare) in fibronectin-coated flasks (Corning) at $37^{\circ} \mathrm{C}$ and $5 \% \mathrm{CO}_{2}$ atmosphere.

For pneumococcal infections or $\mathrm{H}_{2} \mathrm{O}_{2}$ stimulations, $3 \times 10^{5}$ cells/well were seeded in 24-well tissue culture plates (Greiner) and maintained at $37^{\circ} \mathrm{C}$ and $5 \% \mathrm{CO}_{2}$ atmosphere. All experiments were performed in minimum essential media. The cells were either infected with bacteria (MOI 50) or stimulated with different concentrations of $\mathrm{H}_{2} \mathrm{O}_{2}$ for 2,4 , or $6 \mathrm{~h}$. To activate NLRP3 inflammasome, additional experiments included $4 \mathrm{~h}$ of $100 \mathrm{ng} / \mathrm{mL} \mathrm{LPS}$ or $100 \mathrm{ng} /$ $\mathrm{mL}$ TNFa cell stimulations prior to an infection or $\mathrm{H}_{2} \mathrm{O}_{2}$ stimulation. To inactivate $\mathrm{H}_{2} \mathrm{O}_{2}$-mediated actions, $300 \mathrm{U} / \mathrm{mL}$ of catalase was added to the experiments.

To assess bacterial infectivity, 16HBE cells were infected with pneumococci for 2, 4, or $6 \mathrm{~h}$. At indicated time points, the cells were washed, detached, lysed, and the viable counts of pneumococci (colony-forming units) released from lysed cells were determined by plating serial dilutions on blood agar.

\section{Caspase-1 and Caspase-3/7 Activities}

All infection and stimulation experiments were performed as described above. Four hours post infections/stimulation, active caspase- 1 and caspase-3/7 were labeled with cell-permeable fluorescent probes FAM-YVAD-FMK FLICA or FAM-DEVD-FMK FLICA (both Bio-Rad) according to the manufacturer's instructions. The cell nuclei were stained with Nuclear-ID Red DNA stain (Enzo Life Sciences). The staining was visualized using an Axio Observer Z1 microscope (Zeiss). To quantify the amount of caspase-positive cells, random images were taken and caspase-activated cells are presented as a percentage of caspase-1- or caspase-3/7-active cells in relation to the total cell number.

\section{Cytotoxicity Analysis and IL-1 $\beta$ ELISA}

To determine the cytotoxic responses, supernatants of bacterial infections or $\mathrm{H}_{2} \mathrm{O}_{2}$ cell stimulations were collected and $\mathrm{LDH}$ release from cells was quantified using CytoTox 96 Non-Radioactive Cytotoxicity Assay (Promega) according to the manufacturer's instructions. The IL- $1 \beta$ release was quantified using Human IL-1 beta ELISA (R\&D Systems) according to the manufacturer's instructions. 


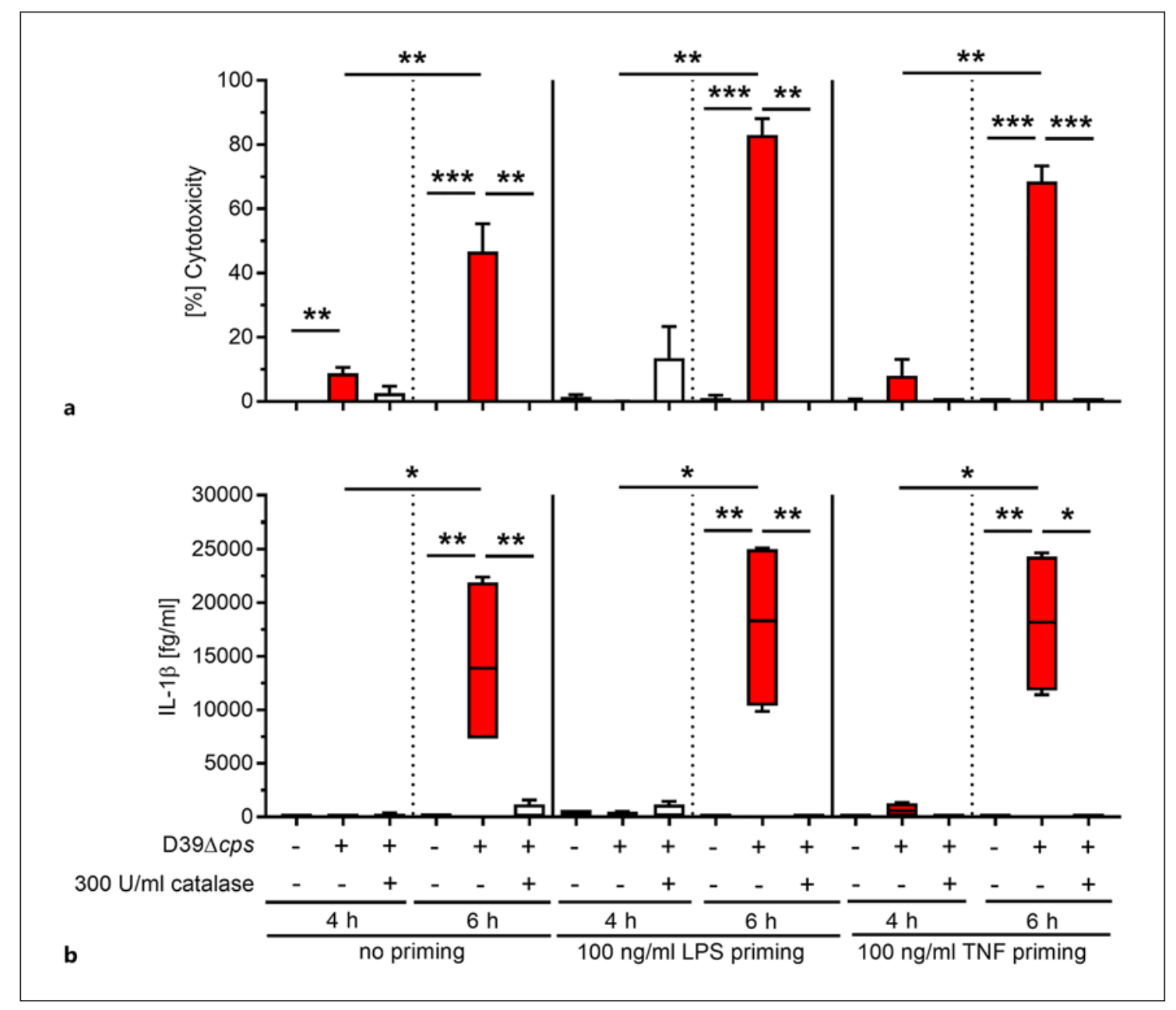

Fig. 1. $\mathrm{H}_{2} \mathrm{O}_{2}$-mediated cytotoxicity and IL-1 $\beta$ release by human bronchial epithelial cells. Unprimed, LPS-, or TNF-primed human bronchial epithelial cells were infected with D39 $\Delta c p s$ at MOI 50 in the presence or absence of catalase for 4 and 6 h. Cytotoxicity (a) and IL-1 $\beta$ release (b) were evaluated at the indicated time points. Bars (a) denote mean values \pm standard deviation (SD). The data in (b) are displayed as box plots. The level of significance was determined using Kruskal-Wallis test with Dunn's post-test $\left(n \geq 4 ;{ }^{*} p<0.05 ;{ }^{* *} p<0.01\right.$; $* * * p<0.001)$.

Inhibition Studies

The irreversible caspase-1 inhibitor Ac-YVAD-cmk (Invivogen), caspase-3/7 inhibitor Ac-DEVD-CHO (Enzo Life Sciences), and NLRP3 inhibitor MCC950 (Invivogen) were used in this study. All inhibitors were dissolved in DMSO and were added to the $16 \mathrm{HBE}$ cells $1 \mathrm{~h}$ prior to the other stimuli. The following concentrations were used: $50 \mu \mathrm{M}$ (Ac-YVAD-cmk and Ac-DEVD$\mathrm{CHO}$ ) and $200 \mathrm{nM}$ (MCC950). Cell treated with 1\% DMSO served as a vehicle control.

\section{SDS-PAGE and Immuno-Detection of Gasdermin D}

$16 \mathrm{HBE}$ cells $\left(1 \times 10^{6} /\right.$ well $)$ were seeded in 6 -well tissue culture plate and stimulated with $150 \mu \mathrm{M} \mathrm{H}_{2} \mathrm{O}_{2}, 150 \mu \mathrm{M} \mathrm{H} \mathrm{H}_{2} \mathrm{O}_{2}$, and $300 \mathrm{U} /$ $\mathrm{mL}$ catalase or left untreated. After $6 \mathrm{~h}$ of incubation, cells were washed and lysed using NP-40 lysis buffer (150 mM NaCl, $1 \%$ [v/v] NP40, 50 mM Tris-HCl, pH 8.0-containing protease inhibi- tor mixture [Cell Signaling Technology]). Samples were normalized to equal amounts of protein $(20 \mu \mathrm{g})$ and boiled in sample buffer (100 mM Tris [pH 6.8], 2\% [w/v] SDS, 10\% [v/v] $\beta$-mercaptoethanol, 20\% [v/v] glycerol, and 0.05\% [w/v] bromophenol blue). As molecular mass marker, prestained protein standards (Bio-Rad) were used. The samples were separated by $12 \%$ SDS-PAGE and transferred to a PVDF membrane. The membranes were blocked with $3 \%(\mathrm{v} / \mathrm{v})$ skim milk prior to primary antibody incubations. Antibody incubations were performed according to manufacturer's guidelines. The following antibodies were used: Gasdermin D (E8G3F) Rabbit mAb, Cleaved Gasdermin D (E7H9G) Rabbit mAb, $\beta$-Actin (D6A8) Rabbit mAb (all from Cell Signaling Technology), and secondary anti-rabbit IgG horseradish peroxidase linked Fab fragment (GE Healthcare). Quantification of the Western blots was performed using ImageJ software. 
Quantitative Reverse Transcription PCR Analysis

Total RNA was isolated from cells using RiboPure RNA Purification Kit (Ambion) according to manufacturer's instructions. cDNA synthesis was performed using Superscript first-strand synthesis system for RT-PCR (Invitrogen). Quantitative reverse transcription PCR was performed using the SYBR GreenER Kit (Bio$\mathrm{Rad})$. All samples were normalized to levels of $\beta$-actin transcription. The following primers were used: NLRP3-for, $5^{\prime}$-GCAAAAAGAGATGAGCCGAAGT-3'; NLRP3-rev, 5' -GCTGTCTTCCTGGCATATCACA-3'; IL-1 $\beta$-for, $5^{\prime}$-CACGATGCACCTGTACGATCA-3'; IL-1 $\beta$-rev, $5^{\prime}$-GTTGCTCCATATCCTGTCCCT-3'; h-betaAct-for, $5^{\prime}$-CTCTTCCAGCCTTCCTTCCT-3'; h-betaActrev, 5'-AGCACTGTGTTGGCGTACAG-3'.

\section{Statistical Analyses}

Statistics were performed using GraphPad Prism version 7.0 (GraphPad). Statistical significance of differences was determined using Kruskal-Wallis test with Dunn's post-test. A $p$ value $<0.05$ was considered significant.

\section{Results}

\section{$\mathrm{H}_{2} \mathrm{O}_{2}$ Produced by Pneumococci Induces Cell Death} and IL-1 $\beta$ Release

Infections of rat alveolar epithelial cells have demonstrated that Ply-deficient $S$. pneumoniae mutants are as cytotoxic as their parental strains [11]. To assess whether $\mathrm{H}_{2} \mathrm{O}_{2}$ production by pneumococci can be directly linked to the cell-damaging events and potentially to inflammasome activation, human bronchial epithelial cells were infected with S. pneumoniae D39 $\Delta c p s$ in the presence or absence of catalase. Potential catalase-mediated bactericidal effects were excluded (online suppl. Fig. 1). Since NLRP3 inflammasome activation involves a priming step for NF$\kappa \mathrm{B}$ activation and subsequent transcription of pro- $I L-1 \beta$ and NLRP3 [38], cells were also stimulated with LPS or TNF $\alpha$ prior to infections. Four and six hours postinfection, cytotoxicity as well as IL- $1 \beta$ release was determined (Fig. 1). While $4 \mathrm{~h}$ of pneumococcal infection remained almost nontoxic to the cells, a significant increase in cytotoxicity was observed at $6 \mathrm{~h}$ postinfection (Fig. 1a). The cytotoxicity was significantly diminished in infections which were supplemented with catalase (Fig. 1a). IL-1 $\beta$ was only detected in cell culture supernatants at $6-\mathrm{h}$ postinfection and only in congruence with the high cell cytotoxicity (Fig. 1b). Both assessed parameters, cytotoxicity and IL- $1 \beta$ release, did not require a priming step.

\section{Active SpxB and Resulting $\mathrm{H}_{2} \mathrm{O}_{2}$ Production Are}

Responsible for the Cell Cytotoxicity

Pneumococci exploit pyruvate oxidase enzyme SpxB to produce $\mathrm{H}_{2} \mathrm{O}_{2}$ [5]. To study the impact of $\mathrm{H}_{2} \mathrm{O}_{2}$ on cell death, isogenic $s p x B$-deficient mutants were constructed. To exclude Ply-mediated cytotoxic effects, ply-deficient mutants were also included in this study. Single ply and $\operatorname{sp} x B$ as well as double mutants were generated in D39 $\Delta$ cps background. In addition to the nucleic acid techniques (Methods section), the knock-outs were also verified via immunoblots targeting Ply and SpxB proteins (online suppl. Fig. 3). Next, functional assays were performed. Growth analyses confirmed that single as well as double knock-outs of $s p x B$ or/and ply in S. pneumoniae $\mathrm{D} 39 \Delta c p s$ did not affect bacterial growth behavior in complex THY media (Fig. 2a). Furthermore, $\mathrm{H}_{2} \mathrm{O}_{2}$ production by all 4 strains was verified. To exclude potential capsule-mediated effects on $\mathrm{H}_{2} \mathrm{O}_{2}$ release, encapsulated wild-type strains were also included in the analysis. SpxB-deficient mutants $(\Delta c p s \Delta s p x B$ and $\Delta c p s \Delta p l y \Delta s p x B)$ produced significantly lower amounts of $\mathrm{H}_{2} \mathrm{O}_{2}$ as compared to D39 $\Delta c p s$ or D39 $\Delta c p s \Delta p l y$ mutants (Fig. 2b). The presence or absence of capsule did not play a role in pneumococcal $\mathrm{H}_{2} \mathrm{O}_{2}$ production and release (Fig. $2 b$ ).

To determine the role of an active SpxB in pneumococcal infections of bronchial epithelial cells, $16 \mathrm{HBE}$ cells were infected with pneumococcal wild-type strains as well as D39 $\Delta c p s$ and its isogenic mutants lacking $s p x B$, ply, or both genes for 2, 4, or $6 \mathrm{~h}$. Total bacterial infectivity (Fig. 2c, e) as well as cytotoxicity toward the cells (Fig. 2d, f) was assessed. After an initial increase of bacterial counts from 2 to $4 \mathrm{~h}$ of infection, a significant drop in infection rates for unencapsulated $s p x B$-positive strains was observed (Fig. 2c). In contrast, the bacterial counts of $s p \times B$ mutants remained at a constant level between 4 and $6 \mathrm{~h}$ of infection (Fig. 2c). Analyses of the cell viability revealed that $16 \mathrm{HBE}$ infections with pneumococci harboring an active $s p x B$ gene were characterized by a time-dependent cell cytotoxicity (Fig. $2 \mathrm{~d}$ ). In contrast, mutant strains lacking $s p x B$ were not cytotoxic (Fig. $2 \mathrm{~d}$ ). To assess if direct contact is required for $\mathrm{H}_{2} \mathrm{O}_{2}$-mediated damage of the cells, infections with encapsulated wild-type strains, which are known to adhere to a lesser extent as compared to the nonencapsulated strains, were also performed. After $4 \mathrm{~h}$ of infection, total infectivity of D39 and TIGR4 was approximately 10 -fold lower compared to the D39 $\Delta c p s$ strain (Fig. 2c, e). 19F strain adhered to the cells even at much lower rates (Fig. 2e). However, the encapsulated wild-type strains were as cytotoxic as the nonencapsulated mutants (Fig. 2d, f). Taken together, these results indicate that cell cytotoxicity at the early stages of infection can be primarily attributed to the influence of $\mathrm{H}_{2} \mathrm{O}_{2}$ produced by pneumococci. 


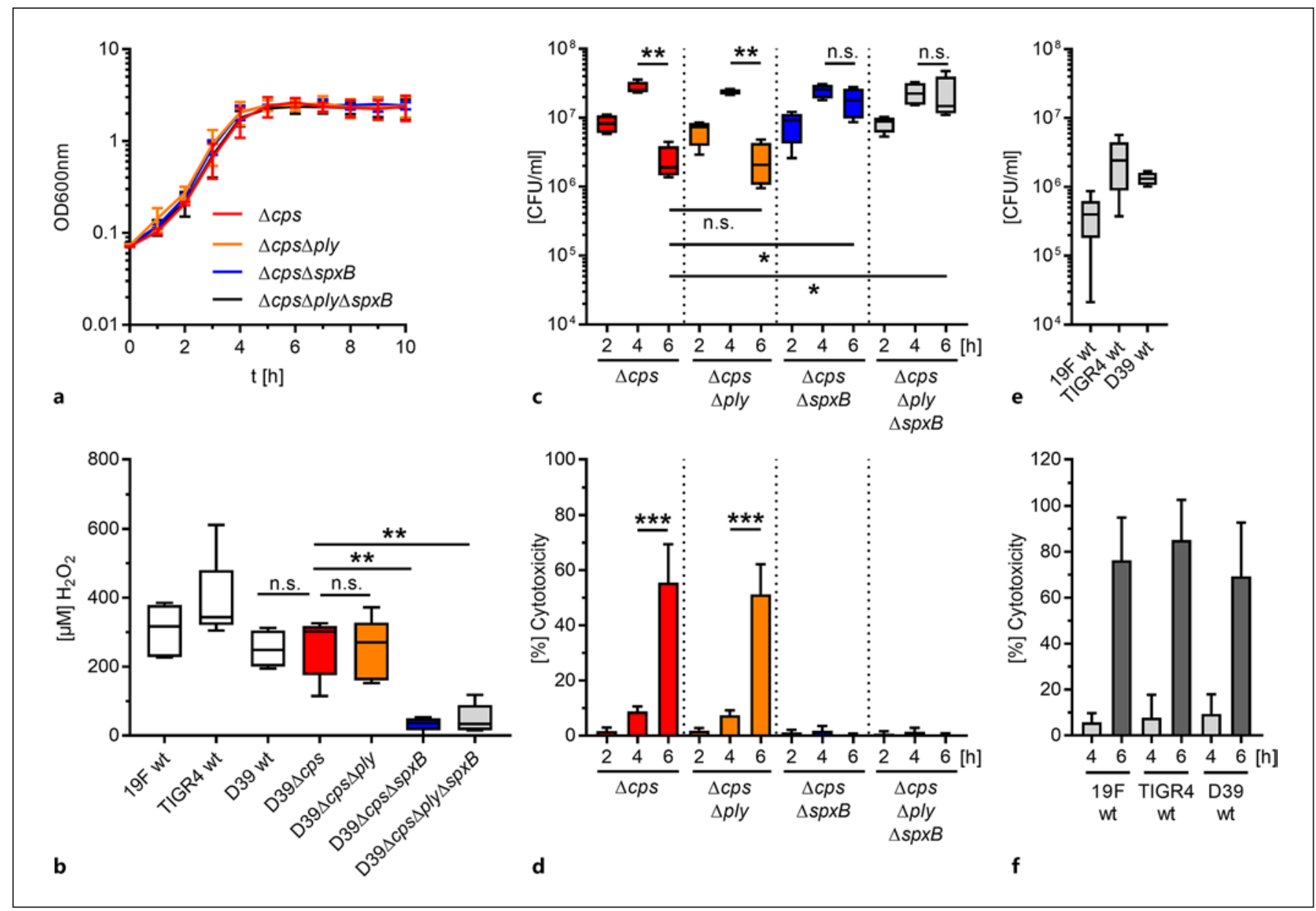

Fig. 2. Pneumococcal $\mathrm{H}_{2} \mathrm{O}_{2}$ is responsible for bronchial epithelial cell lysis. a Monitoring of growth behavior of $S$. pneumoniae $\mathrm{D} 39 \Delta c p s, \Delta c p s \Delta p l y, \Delta c p s \Delta s p x B$, and $\Delta c p s \Delta p l y \Delta s p x B$ mutant strains in THY medium $(n=3)$. $\mathbf{b} \mathrm{H}_{2} \mathrm{O}_{2}$ production by pneumococci was determined by colorimetric analysis of bacterial culture supernatants $(n=4) .16 \mathrm{HBE}$ cells were infected with pneumococcal strains, and bacterial infectivity (c, e) and cytotoxicity toward the cells $(\mathbf{d}, \mathbf{f})$ were assessed at indicated time points $(n \geq 4)$. The data in $(\mathbf{b}, \mathbf{c}, \mathbf{e})$ are displayed as box plots. Bars in $(\mathbf{d}, \mathbf{f})$ denote mean values \pm SD. The level of significance was determined using Kruskal-Wallis test with Dunn's post-test ( $n \geq 4$; n.s., not significant; ${ }^{*} p<0.05 ;{ }^{* *} p<0.01$; $\left.{ }^{* * *} p<0.001\right)$. CFU, colony-forming unit; SD, standard deviation; THY, Todd-Hewitt broth supplemented with $0.5 \%(\mathrm{w} / \mathrm{v})$ yeast extract.

\section{$\mathrm{H}_{2} \mathrm{O}_{2}$ Activates Caspase-1 and Caspase-3/7 in 16HBE Cells}

Both $\mathrm{H}_{2} \mathrm{O}_{2}$-mediated cytotoxicity toward $16 \mathrm{HBE}$ cells and subsequent IL- $1 \beta$ release suggest the involvement of NLRP3 inflammasome in pneumococcal infections. To assess the NLRP3 axis prior to the excessive cell lysis, unprimed 16HBE cells were infected with pneumococcal strains for $4 \mathrm{~h}$ and caspase- 1 activation was determined via fluorescent probing with FAM-YVAD-FMK FLICA. In addition, caspase-3/7 activation as a marker for apoptosis was analyzed. Although initial data indicated that LPS or TNF priming is dispensable, LPS was kept through the entire series of experiments as a generally accepted

$\mathrm{H}_{2} \mathrm{O}_{2}$ Activates NLRP3 Inflammasome inflammasome model control. Only minor cytotoxic events were observed in infections with D39 SpxB-expressing strains (Fig. 3a). Activated caspase-1 was detected in 10-20\% of the infected cells (Fig. 3b, d). In contrast, $s p \times B$ mutants did not cause cell lysis (Fig. 3a) and 16HBE cells remained negative for active caspase-1 (Fig. 3b, d). Analyses of active caspase-3/7 revealed a similar pattern. While infections with SpxB-expressing D39 strains activated caspase-3/7, infections with $s p \times B$ mutants did not (Fig. 3c, d). The observed infection phenotype was independent of priming (Fig. 3 and online suppl. Fig. 4a).

To confirm that the activation of caspases and thereby an increase in cytotoxicity were associated with $\mathrm{H}_{2} \mathrm{O}_{2}$, 


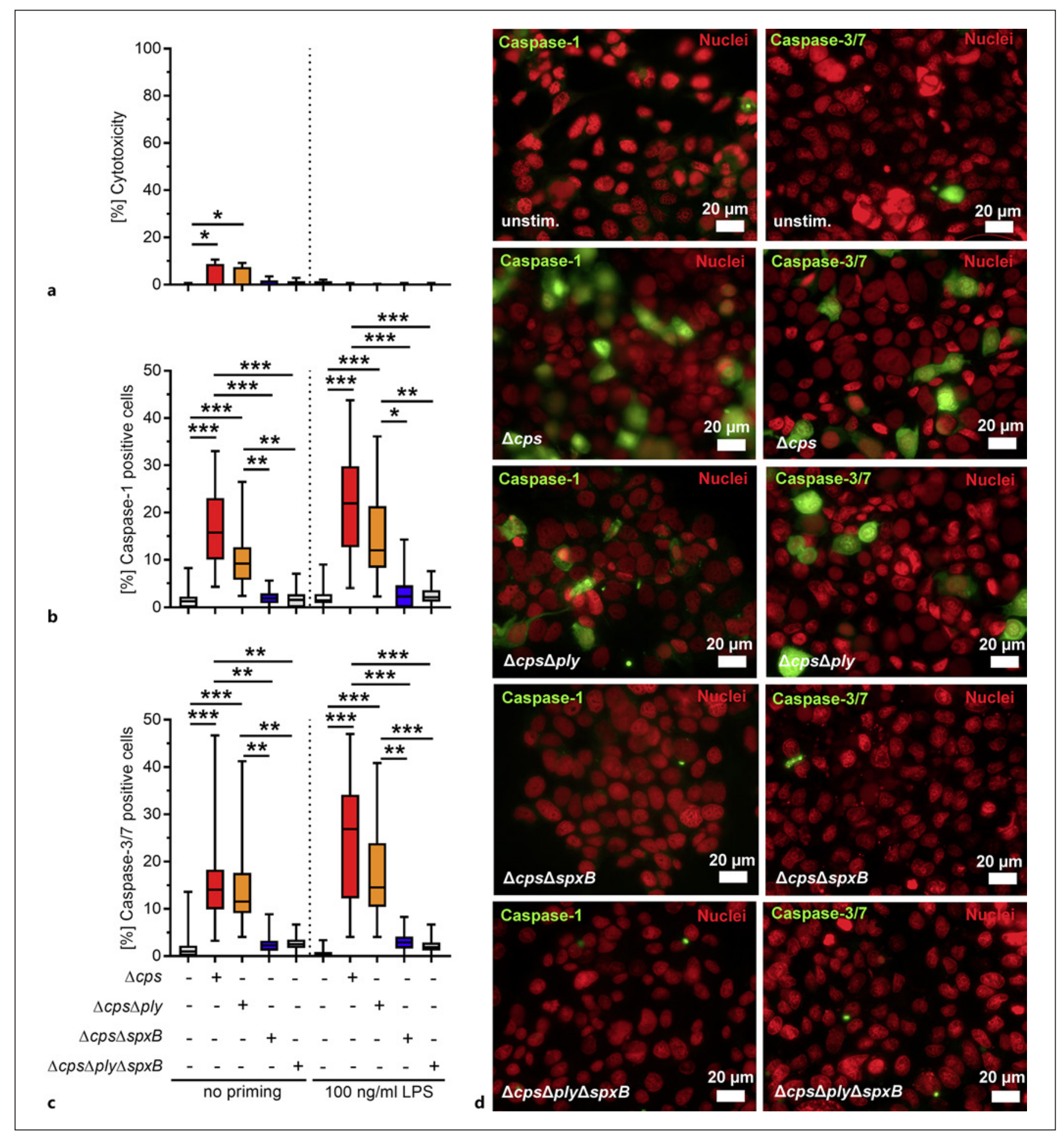

Fig. 3. S. pneumoniae strains with functional $\mathrm{SpxB}$ activate caspase- 1 and caspase-3/7. Unprimed or primed $16 \mathrm{HBE}$ cells were infected with indicated pneumococcal strains for $4 \mathrm{~h}$ and cytotoxicity (a) as well as caspase- 1 and caspase-3/7 (b-d) activation was assessed. The infected cells were stained using fluorescent inhibitor probe FAM-YVAD-FMK (b, d left panel) and FAM-DEVD-FMK (c, $\mathbf{d}$ right panel) to microscopically visualize active caspase-1 and caspase-3/7, respectively. Nuclear-ID stain was used to visualize cell nuclei. Caspase-1- and caspase-3/7-positive cells were counted and are presented as a percentage of positive cells in relation to the total number of cells $(\mathbf{b}, \mathbf{c})$. Bars (a) denote mean values \pm SD. The data in $(\mathbf{b}, \mathbf{c})$ are displayed as box plots. The level of significance was determined using Kruskal-Wallis test with Dunn's post-test $\left(n=4 ;{ }^{*} p<0.05 ;{ }^{* *} p<0.01 ;{ }^{* * *} p<0.001\right)$. SD, standard deviation. 


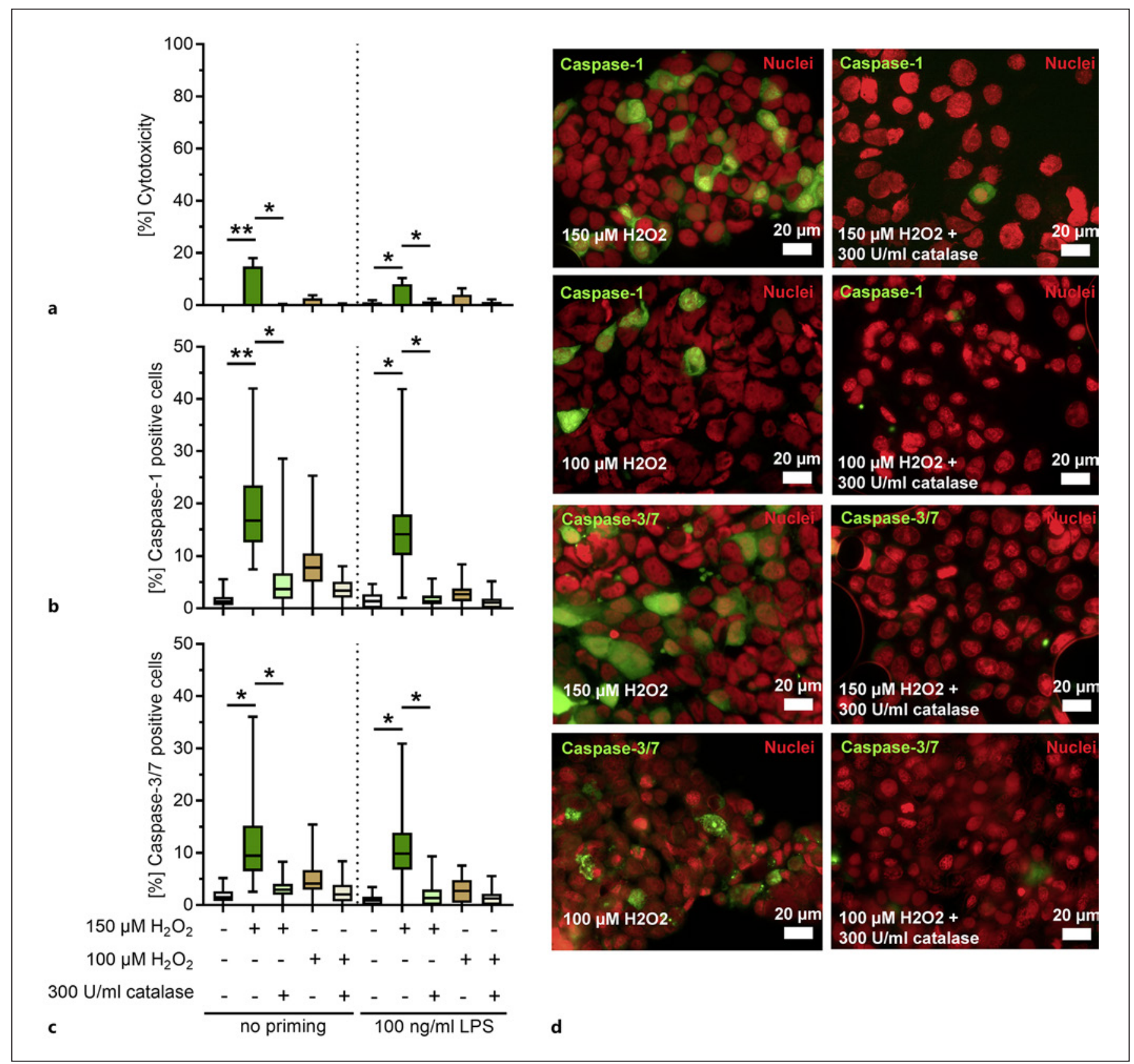

Fig. 4. $\mathrm{H}_{2} \mathrm{O}_{2}$ activates caspase- 1 and caspase- $3 / 7$ in bronchial epithelial cells. Unprimed or primed $16 \mathrm{HBE}$ cells were stimulated with 150 and $100 \mu \mathrm{M} \mathrm{H}_{2} \mathrm{O}_{2}$ in the presence or absence of catalase for $4 \mathrm{~h}$ and cytotoxicity (a) as well as caspase-1 and caspase-3/7 (b-d) activation was assessed. The stimulated cells were stained using fluorescent inhibitor probe FAM-YVAD-FMK (b, d) and FAM-DEVD-FMK (c, d) to microscopically visualize active caspase- 1 and caspase- $3 / 7$, respectively. Nuclear-ID stain was used to visualize cell nuclei. Caspase-1- and caspase-3/7-positive cells were counted and are presented as a percentage of positive cells in relation to the total number of cells $(\mathbf{b}, \mathbf{c})$. Bars (a) denote mean values $\pm \mathrm{SD}$. The data in $(\mathbf{b}, \mathbf{c})$ are displayed as box plots. The level of significance was determined using Kruskal Wallis test with Dunn's post-test $\left(n=4{ }^{*} p<0.05\right.$; ${ }^{* *} p<0.01$; $\left.{ }^{* * *} p<0.001\right)$. SD, standard deviation. 

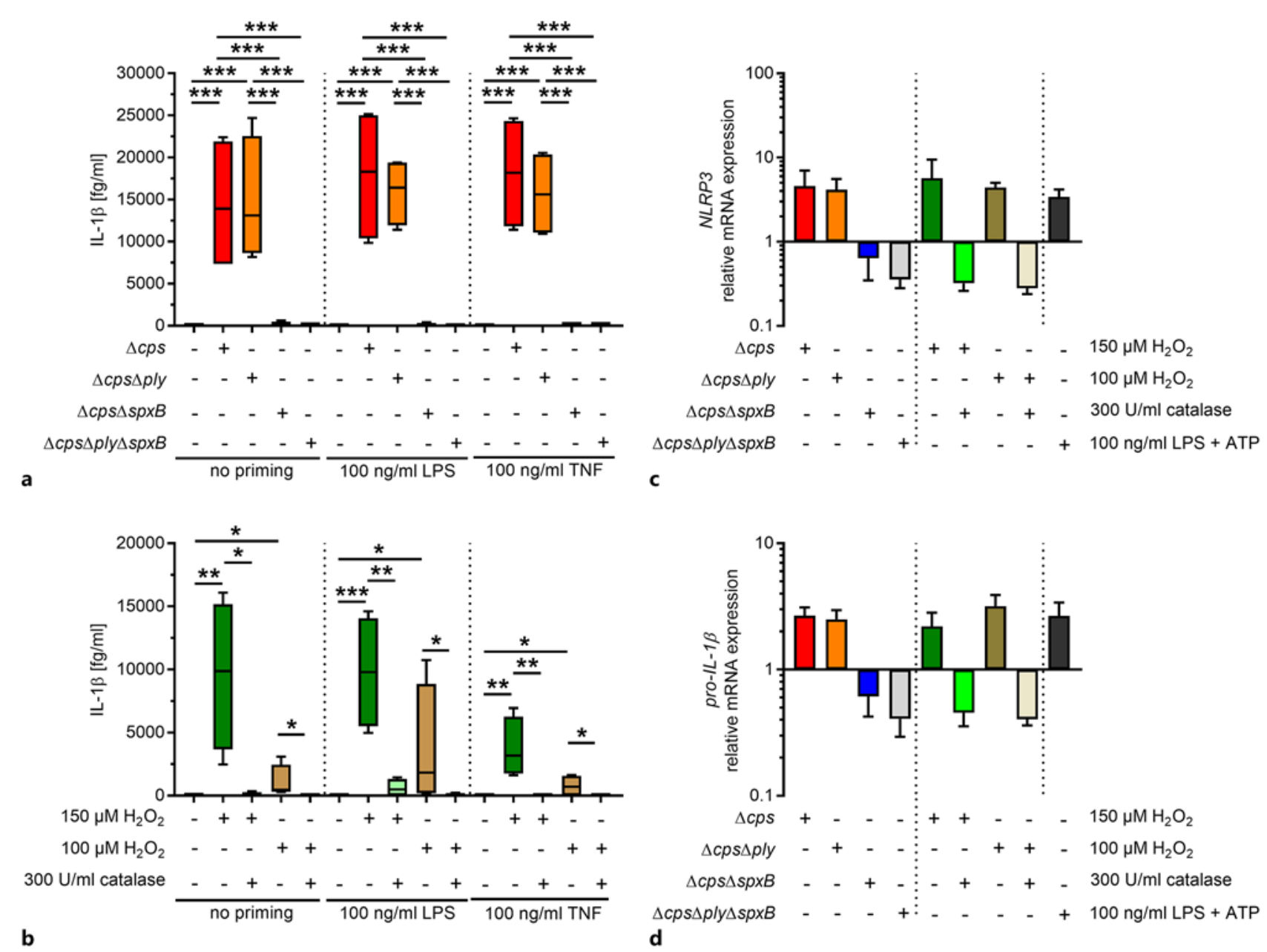

Fig. 5. SpxB-mediated $\mathrm{H}_{2} \mathrm{O}_{2}$ production induces IL- $1 \beta$ release after $6 \mathrm{~h}$ of stimulation. Unprimed, LPS-, or TNF-primed human bronchial epithelial cells were infected with D39 $\Delta$ cps and the isogenic mutants at MOI 50 (a, c, d), or stimulated with 150 and $100 \mu \mathrm{M}$ $\mathrm{H}_{2} \mathrm{O}_{2}$ in the presence or absence of catalase (b-d). IL- $1 \beta$ release was evaluated at $6 \mathrm{~h}$ post infection (a) or stimulation (b). Relative

mRNA expression of NLRP3 (c) and pro-IL-1 $\beta$ (d) was quantified in infected and stimulated cells. The data in (a, b) are displayed as box plots. Bars in (c, d) denote mean values \pm SD. The level of significance was determined using Kruskal-Wallis test with Dunn's post-test $\left(n \geq 4 ;{ }^{*} p<0.05 ;{ }^{* *} p<0.01 ;{ }^{* * *} p<0.001\right)$. SD, standard deviation.

16HBE cells were stimulated with pure $\mathrm{H}_{2} \mathrm{O}_{2}$ for 4 or 6 $\mathrm{h}$. A dose-dependent increase in cytotoxicity toward the cells was observed (online suppl. Fig. 5). Addition of catalase to the stimulations reverted the cytolytic events (online suppl. Fig. 5). $\mathrm{H}_{2} \mathrm{O}_{2}$ concentrations of 100 and $150 \mu \mathrm{M}$, which were approximately of equivalent cytotoxicity as compared to the D39 $\Delta c p s$ strain infections, were used to study the activation of caspases in primed and unprimed cells. Minor cytotoxicity was only observed in stimulations with $150 \mathrm{\mu M} \mathrm{H}_{2} \mathrm{O}_{2}$ (Fig. 4a). Cells with active caspase- 1 were mostly detected in these stim-

ulations (Fig. 4b, d). Furthermore, caspase-3/7 activation followed exactly the same pattern (Fig. 4c, d; online suppl. Fig. 4b). Addition of catalase to the stimulations reduced the $\mathrm{H}_{2} \mathrm{O}_{2}$-mediated cytotoxicity and activation of caspase- 1 and caspase-3/7 (Fig. 4 and online suppl. Fig. 5). These results confirm that $\mathrm{H}_{2} \mathrm{O}_{2}$ induces cell death and caspase- 1 as well as caspase- $3 / 7$ activation in 16HBE cells. 


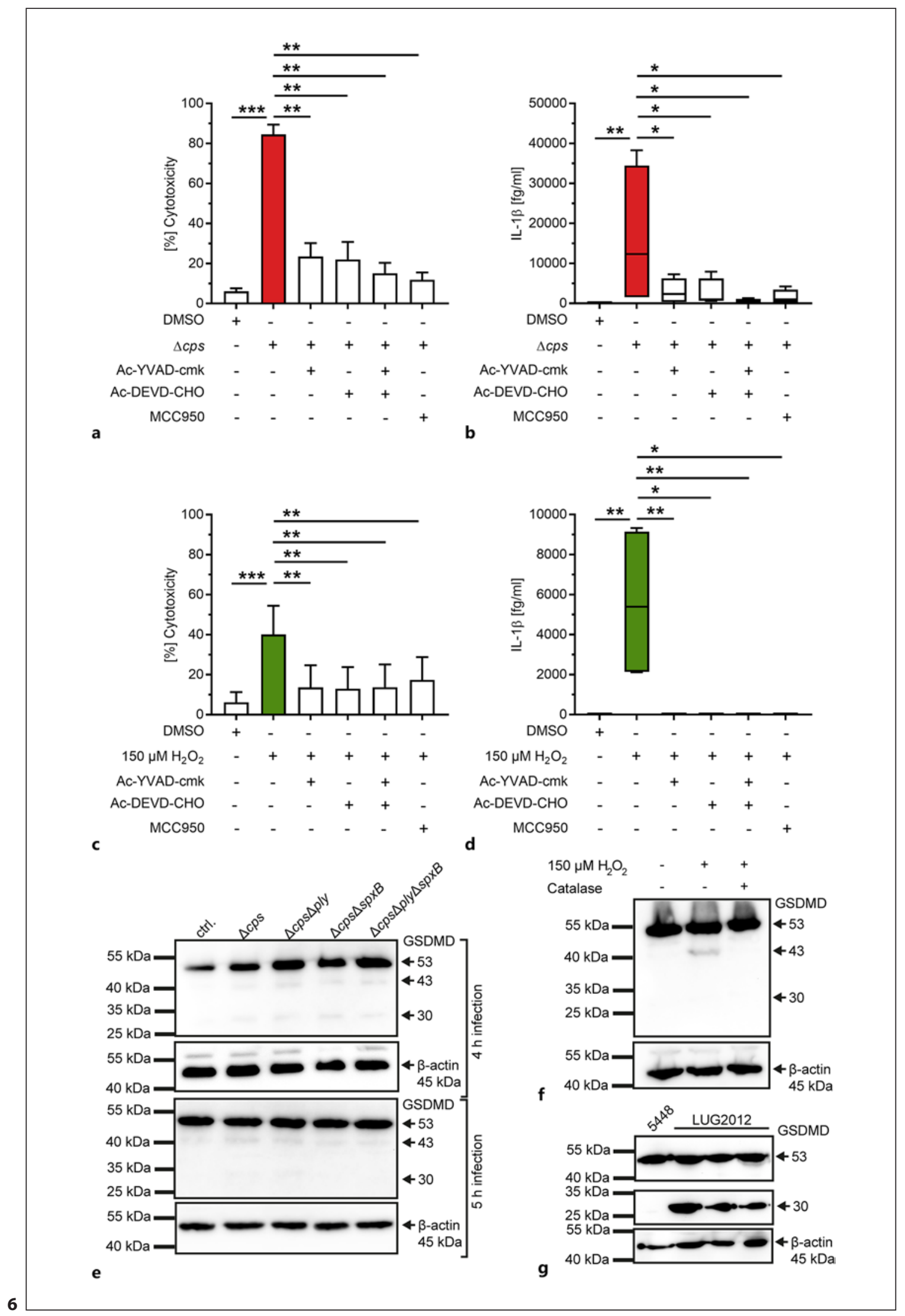

(For legend see next page.) 
$\mathrm{H}_{2} \mathrm{O}_{2}$ Activates Inflammasome Signaling Resulting in IL-1 $\beta$ Release

Since active caspase- 1 cleaves pro-IL- $1 \beta$ into mature form, which is mostly released via pyroptosis, IL-1 $\beta$ release post bacterial infections or $\mathrm{H}_{2} \mathrm{O}_{2}$ stimulations was determined in culture supernatants. To confirm that the priming step is dispensable, TNF and LPS stimulation were performed prior to infections. In line with the cytotoxicity data (Fig. 2d), IL-1 $\beta$ was exclusively detected after $6 \mathrm{~h}$ of infections with SpxB-positive strains (Fig. 5a; online suppl. Fig. $6 \mathrm{a}$ ). $\mathrm{H}_{2} \mathrm{O}_{2}$ stimulations of $16 \mathrm{HBE}$ cells confirmed this phenotype. The highest amounts of IL- $1 \beta$ were detected 6 $\mathrm{h}$ post stimulations (Fig. 5b; online suppl. Fig. 6b). Addition of catalase neutralized $\mathrm{H}_{2} \mathrm{O}_{2}$-mediated IL- $1 \beta$ release.

Our data clearly indicate that $\mathrm{H}_{2} \mathrm{O}_{2}$-mediated cytotoxicity and IL- $1 \beta$ release do not require a priming step. To further delineate the role of $\mathrm{H}_{2} \mathrm{O}_{2}$ in NLRP3 inflammasome activation, NLRP3 and pro-IL- $1 \beta$ mRNA expression in the infected and $\mathrm{H}_{2} \mathrm{O}_{2}$-stimulated cells was analyzed (Fig. 5c, d). Cells stimulated with LPS and ATP served as a positive control. Upregulation in the expression of both genes, NLRP3 and pro-IL-1 $\beta$, was detected in cells infected with D39 $\Delta c p s$ and D39 $\Delta c p s \Delta p l y$ as compared to the $s p \times B$ mutant infections (Fig. 5c, d). Furthermore, both genes were upregulated in response to $\mathrm{H}_{2} \mathrm{O}_{2}$ stimulations (Fig. 5c, d). Addition of catalase reversed this effect. These results confirm that $\mathrm{H}_{2} \mathrm{O}_{2}$ alone is sufficient for priming and activating the NLRP 3 inflammasome in $16 \mathrm{HBE}$ cells.

\section{IL-1 $\beta$ Release Caused by $\mathrm{H}_{2} \mathrm{O}_{2}$ Is a Result of NLRP3}

Inflammasome Activation but Not Pyroptosis

Caspase- 1 activation, cell death, and subsequent IL- $1 \beta$ release are the hallmarks of inflammasome signaling. To

Fig. 6. $\mathrm{H}_{2} \mathrm{O}_{2}$-mediated IL- $1 \beta$ release is a result of NLRP3 inflammasome activation. Unprimed human bronchial epithelial cells were infected with D39 $\Delta c p s$ at MOI $50(\mathbf{a}, \mathbf{b})$, or stimulated with $150 \mu \mathrm{M}$ $\mathrm{H}_{2} \mathrm{O}_{2}$ (c, d). Cells were treated with Ac-YVAD-cmk, Ac-DEVD$\mathrm{CHO}$, and MCC950, $1 \mathrm{~h}$ prior to the other stimuli. Cytotoxicity (a, c) and IL- $1 \beta$ release $(\mathbf{b}, \mathbf{d})$ were evaluated at the 6 -h time point. The data are displayed as box plots. The level of significance was determined using Kruskal-Wallis test with Dunn's post-test $\left(n \geq 4 ;{ }^{*} p<\right.$ $\left.0.05 ;{ }^{* *} p<0.01 ;{ }^{* * *} p<0.001\right)$. Western blot analyses of D39 $\Delta c p s-$ infected (e) and $\mathrm{H}_{2} \mathrm{O}_{2}$-stimulated (f) $16 \mathrm{HBE}$ cells. e $16 \mathrm{HBE}$ cells were infected with different D39 mutant strains or (f) stimulated with $\mathrm{H}_{2} \mathrm{O}_{2}$ for indicated time points, cells were lysed, and $20 \mu \mathrm{g}$ of total protein was separated via SDS-PAGE. Representative images of GSDMD and $\beta$-actin as a loading control from 5 independent experiments are displayed $(n=5)$. $\mathbf{g}$ Western blot analyses of Streptococcus pyogenes 5448 or Staphylococcus aureus LUG2012-infected $16 \mathrm{HBE}$ cells. Original uncropped versions of the blots are shown in online suppl. Fig. 7. GSDMD, gasdermin-D. confirm that these $\mathrm{H}_{2} \mathrm{O}_{2}$-induced responses were indeed mediated via the inflammasome pathway, cells were pretreated with caspase-1 inhibitor Ac-YVAD-cmk or an inhibitor of NLRP3 conformational change and oligomerization MCC950. Since caspase-3/7 activation was also observed, Ac-DEVD-CHO was used to block apoptosis. As previously shown, both $\mathrm{D} 39 \Delta$ cps infections and $\mathrm{H}_{2} \mathrm{O}_{2}$ stimulations of cells for $6 \mathrm{~h}$ resulted in cell death and subsequent IL-1 $\beta$ release (Fig. $6 \mathrm{a}-\mathrm{d}$ ). Blocking of NLRP3, caspase- 1 , caspase- $3 / 7$, or both caspases resulted in significantly diminished cell death and IL- $1 \beta$ amounts in cell culture supernatants (Fig. 6a-d). These results indicate that $\mathrm{H}_{2} \mathrm{O}_{2}$ leads to NLRP3 inflammasome activation and IL- $1 \beta$ production; however, the final IL- $1 \beta$ release is also dependent on the apoptotic cell death pathway. To verify these results, it was essential to determine the GSDMD cleavage products, including full-length GSDMD (50 $\mathrm{kDa}$ ) and fragments of GSDMD cleaved by caspase-1 (30 $\mathrm{kDa}$ ) or caspase-3/7 (43 kDa) (Fig. 6e, f), in infected and $\mathrm{H}_{2} \mathrm{O}_{2}$-stimulated cells. While the 43-kDa GSDMD is inactive, the $30-\mathrm{kDa}$ GSDMN-N is mainly responsible for the cell membrane perforation and pyroptosis. Western blot analyses revealed that full length and small amounts of the inactivated $43-\mathrm{kDa}$ fragment of GSDMD are present in both infected and $\mathrm{H}_{2} \mathrm{O}_{2}$-stimulated cells (Fig. 6e, f; online suppl. Fig 7). No or traces of the $30-\mathrm{kDa}$ product were detected in 5 or $4 \mathrm{~h}$ infections, respectively (Fig. 6e; online suppl. Fig 7). However, 30-kDa GSDMD-N was not detected in any of the pneumococcal infections if a specific antibody was used (online suppl. Fig. 7). To show that GSDMD can be cleaved to GSDMD-N (30 kDa) in $16 \mathrm{HBE}$ cells, infections with $S$. pyogenes 5448 and $S$. aureus LUG2012 were also performed (Fig. 6g). While GSDMD-N was not detected in 5448 infections, it was readily detectable in LUG2012 infections (Fig. 6g). Lack of the active $30-\mathrm{kDa}$ fragment in pneumococcal infections and inhibition studies suggest that the IL- $1 \beta$ release is independent of GSDMD.

\section{Discussion/Conclusion}

Epithelial cells of the respiratory tract are the first responders to an infection or pathogenic stimuli. They respond by secreting various effector molecules such as cytokines and antimicrobial peptides that facilitate an influx of professional phagocytes to engulf the pathogens or infected and dying cells [39]. Here, we report that pneumococci-derived $\mathrm{H}_{2} \mathrm{O}_{2}$ induces epithelial cell cytotoxicity by priming the cells as well as activating the NLRP3 in- 
flammasome, resulting in caspase- 1 activation and IL- $1 \beta$ release. Nevertheless, the final IL- $1 \beta$ release is mainly a result of an apoptotic cell death.

Pneumococci are frequent asymptomatic colonizers of the nasopharyngeal cavity and in certain stress condition; they can disseminate to the lower respiratory tract and cause invasive diseases, including pneumonia [40]. Two major secreted cytotoxins, Ply and $\mathrm{H}_{2} \mathrm{O}_{2}$, are mainly responsible for the lytic injury of a wide range of human cells $[41,42]$. As a pore-forming toxin, Ply is implicated in many cell-damaging processes [43-45]. Previous studies have shown that Ply activates the NLRP3 inflammasome [46]. However, it is noteworthy to mention that Ply is not actively secreted by $S$. pneumoniae due to a lack of an N-terminal signal peptide needed for secretion [47]. Instead, Ply is released via autolysis at the late stage of growth [48]. It has also been shown that Ply-deficient bacteria are as cytotoxic as their respective wild-type strains in the early phase of infection [4]. Therefore, it is plausible to expect that Ply-specific inflammasome activation and cell death occur at the later stages of infection. In contrast to Ply, only 1 study analyzed $\mathrm{H}_{2} \mathrm{O}_{2}$-mediated cell-damaging events in pneumococcal infections. A previous study showed that pneumococci-derived $\mathrm{H}_{2} \mathrm{O}_{2}$ suppresses ATP-mediated inflammasome activation in mouse bone marrow-derived macrophages. The authors proposed that pneumococci utilize $\mathrm{H}_{2} \mathrm{O}_{2}$ to suppress the immune system and through this mechanism, the bacteria might colonize and coexist with the host [28]. In the present study, the cytotoxic impact of pneumococcal $\mathrm{H}_{2} \mathrm{O}_{2}$ on bronchial epithelial cells was analyzed. In contrast to the study mentioned above, infections with $\mathrm{H}_{2} \mathrm{O}_{2}$ producing pneumococci were highly cytotoxic to the epithelial cells. This result is in line with other studies showing that $\mathrm{H}_{2} \mathrm{O}_{2}$ is of cytotoxic nature $[49,50]$. Current literature implicates pneumococcal $\mathrm{H}_{2} \mathrm{O}_{2}$ as a major cause of lung tissue damage through the apoptotic pathways $[51,52]$. However, little is known about its inflammasome-activating properties and pyroptosis. Notably, we find that caspase- 1 and caspase- $-3 / 7$ are activated by $\mathrm{H}_{2} \mathrm{O}_{2}$, indicating that inflammasome activation occurs and potentially both apoptotic and pyroptotic cell death pathways are simultaneously initiated in the presence of $\mathrm{H}_{2} \mathrm{O}_{2}$. Various inflammasome pathways have been studied so far, of which the NLRP3 inflammasome is the most well characterized. It can be activated by a wide range of stimuli, making it very diverse in nature [53]. In contrast to monocytes, the NLRP 3 and pro-IL- $1 \beta$ concentrations in resting epithelial cells are inadequate to initiate activation of the inflammasome, making the priming step manda-

$\mathrm{H}_{2} \mathrm{O}_{2}$ Activates NLRP3 Inflammasome tory [54]. Here, we used LPS and TNF because they are commonly accepted priming agents in inflammasomerelated studies $[23,28,54]$. During a pneumococcal infection in the lung, the role of priming can be also provided by IL- $1 \beta$ itself $[54,55]$. Furthermore, pneumococcal lipoproteins can mediate a TLR2 response [56] and could also play a role in priming. However, our results demonstrate that the priming is dispensable for $\mathrm{H}_{2} \mathrm{O}_{2}$-mediated IL- $1 \beta$ production in pneumococcal infections. This fact is further supported by previous studies which have shown that $\mathrm{H}_{2} \mathrm{O}_{2}$ can directly activate NF- $\kappa \mathrm{B}$ through the NF$\kappa \mathrm{B}$-inducing kinase [57-59].

Furthermore, our data show that caspase-1 or NLRP3 inhibition significantly reduced the $\mathrm{H}_{2} \mathrm{O}_{2}$-mediated cytolytic injury as well as IL- $1 \beta$ release, indicating that $\mathrm{H}_{2} \mathrm{O}_{2}$ is a potent activator of the NLRP3 inflammasome. However, inhibition of the apoptotic pathway followed exactly the same pattern. In support of this, 2 studies demonstrated that $\mathrm{H}_{2} \mathrm{O}_{2}$ induces mitochondrial damage which in turn triggers both apoptotic signals and NLRP3-dependent IL- $1 \beta$ secretion $[51,60]$. In the next step, we aimed to analyze whether $\mathrm{H}_{2} \mathrm{O}_{2}$ mediates pyroptosis. The key molecule in this process is GSDMD. For many years, a linear model of pyroptosis was proposed. Activated caspase- 1 cleaves both pro-IL- $1 \beta$ and GSDMD to IL- $1 \beta$ and GSDMD-N, respectively. The GSDMD-N perforates the lipid bilayer and IL- $1 \beta$ is released through these pores [25]. Although our data demonstrate that $\mathrm{H}_{2} \mathrm{O}_{2}$ induces caspase- 1 activation and IL- $1 \beta$ production, IL- $1 \beta$ release itself occurs in a GSDMD-independent fashion. Only an inactive form of GSDMD (43 kDa), a product of caspase-3 cleavage [61], was detected post $\mathrm{H}_{2} \mathrm{O}_{2}$ stimulations. In line with this, it was suggested that prolonged stimulation of the inflammasome can potentially result in GSDMD-independent cell death and IL-1 $\beta$ release [62].

Nevertheless, cross-talks between the various cell death pathways in a complex cellular environment can still be expected. Recently, it was demonstrated that caspase- 1 can also redundantly promote activation of apoptotic executioner caspase- 3 and caspase-7 in macrophages [63]. Furthermore, caspase- 3 can activate GSDME/DFNA5 to form membrane pores to induce secondary necrotic/pyroptotic cell death $[64,65]$. Even more, cross-talks between pyroptosis and necroptosis have also been reported [66]. Zhao and colleagues have shown that $\mathrm{H}_{2} \mathrm{O}_{2}$ can induce necrosis through the RIP1/RIP3-PARP-AIF pathway [67]. Furthermore, mixed lineage kinase domain-like, a marker for necroptosis, is able to activate the NLRP3 inflammasome and simultaneously rupture the cell membrane, resulting in GSDMD-independent IL- $1 \beta$ release [66]. 
In conclusion, this study strongly supports the concept that pneumococci-derived $\mathrm{H}_{2} \mathrm{O}_{2}$ has a detrimental influence on human bronchial epithelial cells. Although IL-1 $\beta$ release is mainly dependent on the apoptotic pathway, $\mathrm{H}_{2} \mathrm{O}_{2}$ mediates caspase-1-dependent IL- $1 \beta$ production. It is noteworthy to mention that in a complex cellular environment, it is plausible to expect cross-talks between the various cell death pathways. Therefore, to delineate the complex nature of cell death induced by $\mathrm{H}_{2} \mathrm{O}_{2}$, further experimental studies pertaining to other cellular pathways such as necroptosis are warranted.

\section{Acknowledgement}

We would like to acknowledge all partners of the collaborative project "KoInfekt."

\section{Statement of Ethics}

The article is exempt from ethical committee approval as all work was performed in vitro using a cell line and no primary human samples were used.

\section{Conflict of Interest Statement}

The authors declare no conflict of interest.

\section{Funding Sources}

This research was supported by the Federal Excellence Initiative of Mecklenburg Western Pomerania and European Social Fund Grant KoInfekt (ESF_14-BM-A55-0001_16 to S.H.) and the German Research Foundation (DFG; grant no.: 407176682 to N.S.).

\section{Author Contributions}

S.S., S.H., and N.S. designed the study. S.S., L.H.J., P.S., and G.B. performed the experiments. S.S., L.H.J., and N.S. analyzed the data. S.S. and N.S. wrote the manuscript. S.S., L.J., P.S., G.B., S.H., and N.S. read, edited, and reviewed the manuscript.

\section{References}

1 Musher DM, Thorner AR. Community-acquired pneumonia. N Engl J Med. 2014 Oct 23;371(17):1619-28.

2 Kadioglu A, Weiser JN, Paton JC, Andrew PW. The role of Streptococcus pneumoniae virulence factors in host respiratory colonization and disease. Nat Rev Microbiol. 2008 Apr;6(4):288-301.

3 Siemens N, Oehmcke-Hecht S, Mettenleiter TC, Kreikemeyer B, Valentin-Weigand P, Hammerschmidt S. Port d'Entrée for respiratory infections: does the Influenza A virus pave the way for bacteria? Front Microbiol. 2017;8:2602.

4 Cuypers F, Klabunde B, Gesell Salazar M, Surabhi S, Skorka SB, Burchhardt G, et al. Adenosine triphosphate neutralizes pneumolysin-induced neutrophil activation. J Infect Dis. 2020 Oct 13;222(10):1702-12.

5 Spellerberg B, Cundell DR, Sandros J, Pearce BJ, Idänpään-Heikkilä I, Rosenow C, et al. Pyruvate oxidase, as a determinant of virulence in Streptococcus pneumoniae. Mol Microbiol. 1996 Feb;19(4):803-13.

6 Bienert GP, Schjoerring JK, Jahn TP. Membrane transport of hydrogen peroxide. Biochimica Biophysica Acta. 2006 Aug 1;1758(8): 994-1003.
7 Pfister HW, Koedel U, Lorenzl S, Tomasz A. Antioxidants attenuate microvascular changes in the early phase of experimental pneumococcal meningitis in rats. Stroke. 1992 Dec; 23(12):1798-804

8 Hoffmann OM, Becker D, Weber JR. Bacterial hydrogen peroxide contributes to cerebral hyperemia during early stages of experimental pneumococcal meningitis. J Cereb Blood Flow Metab. 2007 Nov;27(11):1792-7.

9 Hirst RA, Sikand KS, Rutman A, Mitchell TJ, Andrew PW, O'Callaghan C. Relative roles of pneumolysin and hydrogen peroxide from Streptococcus pneumoniae in inhibition of ependymal ciliary beat frequency. Infect Immun. 2000 Mar;68(3):1557-62.

10 Feldman C, Anderson R, Cockeran R, Mitchell T, Cole P, Wilson R. The effects of pneumolysin and hydrogen peroxide, alone and in combination, on human ciliated epithelium in vitro. Respir Med. 2002 Aug;96(8):580-5.

11 Duane PG, Rubins JB, Weisel HR, Janoff EN. Identification of hydrogen peroxide as a Streptococcus pneumoniae toxin for rat alveolar epithelial cells. Infect Immun. 1993 Oct; 61(10):4392-7.

12 Crystal RG, Randell SH, Engelhardt JF, Voynow J, Sunday ME. Airway epithelial cells: current concepts and challenges. Proc Am Thorac Soc. 2008;5(7):772-7.
13 Whitsett JA, Alenghat T. Respiratory epithelial cells orchestrate pulmonary innate immunity. Nat Immunol. 2015 Jan;16(1):27-35.

14 LeMessurier KS, Tiwary M, Morin NP, Samarasinghe AE. Respiratory Barrier as a safeguard and regulator of defense against influenza A virus and Streptococcus pneumoniae. Front Immunol. 2020;11:3.

15 Leiva-Juárez MM, Kolls JK, Evans SE. Lung epithelial cells: therapeutically inducible effectors of antimicrobial defense. Mucosal Immunol. 2018;11(1):21-34.

16 Fink SL, Cookson BT. Apoptosis, pyroptosis, and necrosis: mechanistic description of dead and dying eukaryotic cells. Infect Immun. 2005 Apr;73(4):1907-16.

17 Porter AG, Jänicke RU. Emerging roles of caspase-3 in apoptosis. Cell Death Differ. 1999 Feb;6(2):99-104

18 Surabhi S, Cuypers F, Hammerschmidt S, Siemens N. The role of NLRP3 inflammasome in pneumococcal infections. Front Immunol. 2020December 14;11(3277):614801.

19 Lamkanfi M, Dixit VM. Modulation of inflammasome pathways by bacterial and viral pathogens. J Immunol. 2011 Jul 15;187(2): 597-602. 
20 Amores-Iniesta J, Barberà-Cremades $\mathrm{M}$, Martínez CM, Pons JA, Revilla-Nuin B, Martínez-Alarcón L, et al. Extracellular ATP activates the NLRP3 inflammasome and is an early danger signal of skin allograft rejection. Cell Rep. 2017 Dec 19;21(12):3414-26.

21 Eigenbrod T, Dalpke AH. Bacterial RNA: an underestimated stimulus for innate immune responses. J Immunol. 2015 Jul 15;195(2): 411-8.

22 Greaney AJ, Leppla SH, Moayeri M. Bacterial exotoxins and the inflammasome. Front Immunol. 2015 November 10;6(570):570.

23 Netea MG, Nold-Petry CA, Nold MF, Joosten LA, Opitz B, van der Meer JH, et al. Differential requirement for the activation of the inflammasome for processing and release of ILlbeta in monocytes and macrophages. Blood. 2009 Mar 5;113(10):2324-35.

24 Gritsenko A, Yu S, Martin-Sanchez F, del Olmo ID, Nichols EM, Davis DM, et al. Priming is dispensable for NLRP3 inflammasome activation in human monocytes. Front Immunol. 2020 Sep 30;11:565924.

25 He WT, Wan H, Hu L, Chen P, Wang X, Huang Z, et al. Gasdermin D is an executor of pyroptosis and required for interleukin- $1 \beta$ secretion. Cell Res. 2015 Dec;25(12):1285-98.

26 Shi J, Zhao Y, Wang K, Shi X, Wang Y, Huang $\mathrm{H}$, et al. Cleavage of GSDMD by inflammatory caspases determines pyroptotic cell death. Nature. 2015 Oct 29;526(7575):660-5.

27 Liu X, Zhang Z, Ruan J, Pan Y, Magupalli VG, $\mathrm{Wu} \mathrm{H}$, et al. Inflammasome-activated gasdermin $\mathrm{D}$ causes pyroptosis by forming membrane pores. Nature. 2016 Jul 7;535(7610): 153-8.

28 Erttmann SF, Gekara NO. Hydrogen peroxide release by bacteria suppresses inflammasome-dependent innate immunity. Nat Commun. 2019 Aug 2;10(1):3493.

29 Dostert C, Pétrilli V, Van Bruggen R, Steele C, Mossman BT, Tschopp J. Innate immune activation through Nalp3 inflammasome sensing of asbestos and silica. Science. 2008 May 2;320(5876):674-7.

30 Zhou R, Tardivel A, Thorens B, Choi I, Tschopp J. Thioredoxin-interacting protein links oxidative stress to inflammasome activation. Nat Immunol. 2010 Feb;11(2):136-40.

31 Siemens N, Chakrakodi B, Shambat SM, Morgan $\mathrm{M}$, Bergsten $\mathrm{H}$, Hyldegaard O, et al. Biofilm in group A streptococcal necrotizing soft tissue infections. JCI Insight. 2016 Jul 7; 1(10): e87882.

32 Mairpady Shambat S, Chen P, Nguyen Hoang AT, Bergsten H, Vandenesch F, Siemens N, et al. Modelling staphylococcal pneumonia in a human 3D lung tissue model system delineates toxin-mediated pathology. Dis Model Mech. 2015 Nov;8(11):1413-25.

33 Hammerschmidt S, Talay SR, Brandtzaeg P, Chhatwal GS. SpsA, a novel pneumococcal surface protein with specific binding to secretory immunoglobulin A and secretory component. Mol Microbiol. 1997 Sep;25(6):111324.
34 Gómez-Mejia A, Gámez G, Hirschmann S, Kluger V, Rath H, Böhm S, et al. Pneumococcal metabolic adaptation and colonization are regulated by the two-component regulatory system 08. mSphere. 2018 MayJun;3(3): e00165-18.

35 Battig P, Muhlemann K. Influence of the spxB gene on competence in Streptococcus pneumoniae. J Bacteriol. 2008 Feb;190(4):1184-9.

36 Schmidt F, Kakar N, Meyer TC, Depke M, Masouris I, Burchhardt G, et al. In vivo proteomics identifies the competence regulon and AliB oligopeptide transporter as pathogenic factors in pneumococcal meningitis. PLoS Pathog. 2019 Jul;15(7):e1007987.

37 Schulz C, Gierok P, Petruschka L, Lalk M, Mäder U, Hammerschmidt S. Regulation of the arginine deiminase system by ArgR2 interferes with arginine metabolism and fitness of Streptococcus pneumoniae. mBio. 2014 Dec 23;5(6):e01858-14.

38 Zheng D, Liwinski T, Elinav E. Inflammasome activation and regulation: toward a better understanding of complex mechanisms. Cell Discov. 2020;6(1):36.

39 Bals R. Epithelial antimicrobial peptides in host defense against infection. Respir Res. 2000;1(3):141-50.

40 Song JY, Nahm MH, Moseley MA. Clinical implications of pneumococcal serotypes: invasive disease potential, clinical presentations, and antibiotic resistance. J Korean Med Sci. 2013 Jan;28(1):4-15.

41 Kim JY, Paton JC, Briles DE, Rhee DK, Pyo S Streptococcus pneumoniae induces pyroptosis through the regulation of autophagy in murine microglia. Oncotarget. 2015 Dec 29; 6(42):44161-78.

42 Brooks LRK, Mias GI. Streptococcus pneumoniae's virulence and host immunity: aging, diagnostics, and prevention. Front Immunol. 2018;9:1366.

43 Witzenrath M, Pache F, Lorenz D, Koppe U, Gutbier B, Tabeling C, et al. The NLRP3 inflammasome is differentially activated by pneumolysin variants and contributes to host defense in pneumococcal pneumonia. J Immunol. 2011 Jul 1;187(1):434-40.

44 Fatykhova D, Rabes A, Machnik C, Guruprasad K, Pache F, Berg J, et al. Serotype 1 and 8 Pneumococci evade sensing by inflammasomes in human lung tissue. PLoS One. 2015; 10(8): 0137108.

45 Jahn K, Handtke S, Palankar R, Weißmüller S, Nouailles G, Kohler TP, et al. Pneumolysin induces platelet destruction, not platelet activation, which can be prevented by immunoglobulin preparations in vitro. Blood Adv. 2020 Dec 22;4(24):6315-26.

46 McNeela EA, Burke A, Neill DR, Baxter C, Fernandes VE, Ferreira D, et al. Pneumolysin activates the NLRP3 inflammasome and promotes proinflammatory cytokines independently of TLR4. PLoS Pathog. 2010 Nov 11; 6(11):e1001191.
47 Walker JA, Allen RL, Falmagne P, Johnson MK, Boulnois GJ. Molecular cloning, characterization, and complete nucleotide sequence of the gene for pneumolysin, the sulfhydrylactivated toxin of Streptococcus pneumoniae. Infect Immun. 1987;55(5):1184-9.

48 Benton KA, Paton JC, Briles DE. Differences in virulence for mice among Streptococcus pneumoniae strains of capsular types 2, 3, 4, 5 , and 6 are not attributable to differences in pneumolysin production. Infect Immun. 1997;65(4):1237-44.

49 Brissac T, Shenoy AT, Patterson LA, Orihuela CJ. Cell Invasion and pyruvate oxidase-derived $\mathrm{H}(2) \mathrm{O}(2)$ are critical for Streptococcus pneumoniae-mediated cardiomyocyte killing. Infect Immun. 2018 Jan;86(1):e00569-17.

50 Gao Y, Xu W, Dou X, Wang H, Zhang X, Yang $S$, et al. Mitochondrial DNA leakage caused by Streptococcus pneumoniae hydrogen peroxide promotes type I IFN expression in lung cells. Front Microbiol. 2019;10:630.

51 Braun JS, Sublett JE, Freyer D, Mitchell TJ, Cleveland JL, Tuomanen EI, et al. Pneumococcal pneumolysin and $\mathrm{H}(2) \mathrm{O}(2)$ mediate brain cell apoptosis during meningitis. J Clin Invest. 2002 Jan;109(1):19-27.

52 Rai P, Parrish M, Tay IJJ, Li N, Ackerman S, $\mathrm{He}$ F, et al. Streptococcus pneumoniae secretes hydrogen peroxide leading to DNA damage and apoptosis in lung cells. Proc Natl Acad Sci U S A. 2015;112(26):E3421-30.

53 Man SM, Karki R, Kanneganti TD. Molecular mechanisms and functions of pyroptosis, inflammatory caspases and inflammasomes in infectious diseases. Immunol Rev. 2017 May; 277(1):61-75.

54 Kelley N, Jeltema D, Duan Y, He Y. The NLRP3 Inflammasome: an overview of mechanisms of activation and regulation. Int $\mathrm{J} \mathrm{Mol}$ Sci. 2019 Jul 6;20(13):3328.

55 Swanson KV, Deng M, Ting JP-Y. The NLRP3 inflammasome: molecular activation and regulation to therapeutics. Nat Rev Immunol. 2019;19(8):477-89.

56 Tomlinson G, Chimalapati S, Pollard T, Lapp $\mathrm{T}$, Cohen J, Camberlein E, et al. TLR-mediated inflammatory responses to Streptococcus pneumoniae are highly dependent on surface expression of bacterial lipoproteins. J Immunol. 2014 Oct 1;193(7):3736-45.

57 Schreck R, Rieber P, Baeuerle PA. Reactive oxygen intermediates as apparently widely used messengers in the activation of the NFkappa B transcription factor and HIV-1. EMBO J. 1991 Aug;10(8):2247-58.

58 Li Q, Sanlioglu S, Li S, Ritchie T, Oberley L, Engelhardt JF. GPx-1 gene delivery modulates $\mathrm{NF \kappa B}$ activation following diverse environmental injuries through a specific subunit of the IKK complex. Antioxid Redox Signal. 2001 Jun;3(3):415-32.

59 Zhang J, Johnston G, Stebler B, Keller ET. Hydrogen peroxide activates $\mathrm{NF \kappa B}$ and the interleukin-6 promoter through NFkBinducing kinase. Antioxid Redox Signal. 2001 Jun;3(3):493-504. 
60 Shimada K, Crother TR, Karlin J, Dagvadorj J, Chiba N, Chen S, et al. Oxidized mitochondrial DNA activates the NLRP3 inflammasome during apoptosis. Immunity. $2012 \mathrm{Mar}$ 23;36(3):401-14.

61 Taabazuing CY, Okondo MC, Bachovchin DA. Pyroptosis and apoptosis pathways engage in bidirectional crosstalk in monocytes and macrophages. Cell Chem Biol. 2017 Apr 20;24(4):507-e4.

62 Monteleone M, Stanley AC, Chen KW, Brown DL, Bezbradica JS, von Pein JB, et al. Interleukin- $1 \beta$ maturation triggers its relocation to the plasma membrane for gasderminD-dependent and -independent secretion. Cell Rep. 2018 Aug 7;24(6):1425-33.
63 de Vasconcelos NM, Van Opdenbosch N, Van Gorp H, Martín-Pérez R, Zecchin A, Vandenabeele $\mathrm{P}$, et al. An apoptotic caspase network safeguards cell death induction in pyroptotic macrophages. Cell Rep. $2020 \mathrm{Jul}$ 28;32(4):107959.

64 Rogers C, Fernandes-Alnemri T, Mayes L, Alnemri D, Cingolani G, Alnemri ES. Cleavage of DFNA5 by caspase-3 during apoptosis mediates progression to secondary necrotic/ pyroptotic cell death. Nat Commun. 2017 Jan 3;8:14128.
65 de Vasconcelos NM, Lamkanfi M. Recent insights on inflammasomes, gasdermin pores, and pyroptosis. Cold Spring Harb Perspect Biol. 2020 May 1;12(5):a036392.

66 Gutierrez KD, Davis MA, Daniels BP, Olsen TM, Ralli-Jain P, Tait SWG, et al. MLKL activation triggers NLRP3-mediated processing and release of IL- $1 \beta$ independently of gasdermin-D. J Immunol. 2017 Mar 1;198(5):215664.

67 Zhao L, Lin H, Chen S, Chen S, Cui M, Shi D, et al. Hydrogen peroxide induces programmed necrosis in rat nucleus pulposus cells through the RIP1/RIP3-PARP-AIF pathway. J Orthop Res. 2018 Apr;36(4):1269-82. 